\title{
Evaluating compliance with Australia's first smoke-free public places legislation
}

\author{
Margo Goodin, Ian McAllister
}

\begin{abstract}
Objective-To measure the level of compliance among businesses with legislation prohibiting smoking in public places.

Design-A representative sample of businesses in the Australian Capital Territory (ACT) was selected. A two-phase survey design was used: in phase 1 , interviewers observed business premises to evaluate their compliance with the legislation, observing the display of no-smoking signs and noting any evidence of smoking in smoking-prohibited areas; in phase 2, a short questionnaire was completed by the business owner or manager.
\end{abstract}

Setting-Observations of business premises and self-completion interviews with owners or managers of those premises.

Subjects-938 respondents who were either owners, managers, or employees of ACT businesses.

Main outcome measures-Compliance with legislation prohibiting smoking in the public areas of business premises; businesses' own perceptions of the extent of their compliance; and the factors affecting the discrepancy between actual and perceived compliance.

Results-A total of $22 \%$ of the businesses complied fully with the legislation, whereas $56 \%$ partially complied by displaying external or internal signage. Most respondents ( $84 \%$ ) believed that they were complying fully with the legislation. Only $21 \%$ of the businesses complied and correctly assessed their compliance. Evidence of smoking was detected in only $5 \%$ of no-smoking premises. The type of business and the smoking policy of the establishment at the time the legislation came into force were important influences on compliance, followed by whether the premises were free-standing or located within shopping malls. The mass media was identified as the main source of information about the legislation.

Conclusions-Ensuring the successful implementation of non-smoking legislation is facilitated by (a) widespread publicity to make business proprietors and their customers and clients aware of the legislation; (b) first implementing legislation in premises where there is strong public support for such measures; and (c) targeting information to premises that have pre-existing policies prohibiting smoking on their premises.

(Tobacco Control 1997;6:326-331)

Keywords: compliance, non-smoking legislation, smoke-free worksites

\section{Introduction}

Ever since environmental tobacco smoke (ETS) became widely recognised as a health hazard to non-smokers, ${ }^{1-4}$ governments in many countries have sought to prohibit or restrict smoking in enclosed public places. Workplaces have been singled out for particular attention, due to the long duration and high frequency with which employees are exposed to ETS. More recently, there has been increasing interest in regulatory action aimed at restricting or prohibiting smoking in the hospitality sector, where voluntary policies and self-regulation have had only limited effect. This sector has not responded to customer preferences, ${ }^{5}$ and employees are afforded little protection from frequent ETS exposure.

Progress towards implementing bans on smoking in public places has varied from country to country. A 1986 resolution by the World Health Organisation declared that passive smoking "violates the right to health of non-smokers" and urged member states to ensure that "non-smokers receive effective protection, to which they are entitled, from involuntary exposure to tobacco smoke, in enclosed public places, restaurants, transport, and places of work and entertainment." Although the European Community passed a resolution in 1989 encouraging member states to implement smoking prohibitions, with the exception of France, very few European countries have followed this lead, ${ }^{6}{ }^{7}$ despite apparently strong public support. ${ }^{8}$

In North America, moves to prohibit smoking in public places have been more rapid. In the United States, state legislation was first enacted in the 1970 s, with state laws and local ordinances increasing rapidly (and, in many cases, strengthening) during the 1980s and 1990s. By 1989, no fewer than 44 states and more than 500 cities had laws restricting smoking in public places and workplaces ${ }^{9}$ (Rigotti et al, unpublished paper and personal correspondence, 1995). In Canada, more than 39 cities and towns had enacted bylaws regulating smoking in public places by the end of the 1980 s. $^{10}$ Most studies have reported that such laws have had no net detrimental economic impact on the hospitality industry ${ }^{11-14}$ or on tourism (Letter from HA Silas, Department of 
Health Services, County of San Diego to Dr Michael Siegel, 1992).

In Australia, a number of major employers had introduced smoking restrictions or prohibitions by the early 1990s, including airlines, airports, state and federal government offices, banks, and police stations. There has also been considerable public debate about restricting smoking in other public places, such as shopping centres, restaurants, and cafés. ${ }^{1516}$ However, despite strong public support for wider ranging bans than currently exist, ${ }^{5} 1718$ there was, until 1994, no legislation requiring restaurants or other enclosed public places to restrict or prohibit smoking other than for reasons of safety and hygiene. The Australian Capital Territory's (ACT's) Smoke-Free Areas (Enclosed Public Places) Act 1994 is Australia's only smoke-free indoor environment legislation enacted specifically to protect against involuntary exposure to ETS. The ACT is a self-governing territory with both state and municipal functions, with an elected assembly of 17 members.

A major issue with regard to prohibiting or restricting smoking in private premises open to the public is compliance, especially as such laws tend to rely on self-enforcement. ${ }^{19}{ }^{20}$ Legislation which does not receive widespread compliance among both proprietors and customers not only fails to further the health goals of the legislation, but hampers any further attempts at reform by bringing the law into contempt. However, the first systematic assessment of compliance with the public place provisions of a state or city no-smoking law was only published in $1993 .{ }^{9}$ The paucity of case studies examining business and customer compliance with smoking restrictions in private premises means that policy makers have little data on which to base their strategies.

The few studies that have been conducted have come to several conclusions. High levels of compliance are associated with high levels of awareness of the law, ${ }^{19}{ }^{21}$ although awareness of the law does not necessarily imply knowledge of its provisions. There is also evidence that the display of no-smoking signs has a crucial role in self-enforcement, ${ }^{9}$ because: (a) they act as a constant reminder of the policy, and (b) they create an anti-smoking environment. However, without periodic reminders by public officials, compliance may decline over time. ${ }^{10}$ Complaints to health authorities about infringements of the policy do not appear to be a reliable measure of compliance. ${ }^{9}$

This article examines businesses' compliance with ACT legislation restricting smoking in private premises accessible to the public. More specifically, we consider the results of a representative survey of local businesses, conducted after the legislation had been in effect for six months, to examine (a) whether or not the premises complied with the legislation; (b) whether the proprietors themselves thought that they complied with the legislation; and (c) the factors that appeared to influence compliance.
ACT SMOKE-FREE ENCLOSED PUBLIC PLACES LEGISLATION

음

Although all public-sector and a number of private-sector employers in the ACT introduced restrictions on smoking बैuring the 1980 s and early 1990 s, prohibiting restricting smoking in the public areas of môst private premises was, until 1994, voluntagy. Where they were introduced, smoking p perhibitions tended to be prompted by occupational health and safety concerns rather than out of $_{\text {concern }}$ for clients or patrons. Before 1994 smoking was prohibited in the common areasof one of the ACT's four major town centre-shopping malls and in several large department stores. Although there were a number of no: restaurants and cafés, governmentostimates suggested that less than $20 \%$ of the ACT's 600 restaurants and cafes offered smoke-fopee dining or designated smoking and noB-smoking dining areas.

Although many business proprieto $\vec{s}$ claimed that they were waiting for the gove 8 nment to introduce uniform smoking restrictiôn, public opinion appeared ready to surport the introduction of smoking restrictions, A 1991 survey of more than 500 adults that three-quarters of those interviewed favoured the prohibition of smoking in all encosed public places, with support for such piohibitions ranging from $63 \%$ for public ötransport terminals to more than $80 \%$ for banfos, department stores and shops, and more than $90 \%$ for food stores, cinemas, and theatres. Wen asked about smoking in restaurants, $97 \%$ favoured restriction or prohibition; only 3\% favoured unrestricted smoking. Three times.as many respondents said they would be morely tike eat where smoking was prohibited asiwould be less likely to eat there. ${ }^{22}$

Although levels of smoking in the्ठACT are similar to those found elsewhere in Australia, the Territory differs in several respects from the rest of the country. As the fedegil capital, the population of a third of a millio is highly educated, with high average incomess. Nearly half of the workforce is employed by government, which has had sinoke-free workplace policies since the late $\$ 980$ s. In addition, the legislation attracted crioss-party support in the elected assembly, an की the then opposition leader was a pharmacist wijth a keen interest in health issues. Although the national tobacco industry opposed the begislation, organised objections came mainly from the hospitality and tourism sector..$^{23}$ The legislation was strongly supported by the peak body representing trade unions, although not by all individual unions.

$\stackrel{\text { 两 }}{\text { pation, the }}$

Before the introduction of the legispation, the in late 1993. This was followed by $\bar{F}_{a}$ further consultation and inquiry by an OAssembly standing committee in 1994. The fiepal legislation was passed in September 1996 with the first smoking restrictions and prohib tions taking effect in December 1994. The Act prohibits smoking in a wide range of enclosed (indoor) public places, including restaurants, shops, and shopping centres. During the first 
year, restaurants, cafés, and other enclosed public dining areas were required to prohibit smoking in a minimum of $50 \%$ of the dining area. The legislation is based on selfenforcement, with government health inspectors responding to complaints and providing compliance to proprietors. The Act provides for fines of up to $\$ \mathrm{~A} 500$ for smoking in a smoking-prohibited area and up to $\$ A 5000$ for a proprietor's failure to comply with the legislation. To date, one legal action has been brought against a proprietor for noncompliance.

The legislation required proprietors of businesses to show approved signage prohibiting smoking in their premises. Three types of signs were available from the government, each printed in red and black ink on a white background, displaying the international no-smoking symbol, in addition to one of the following messages: "No smoking please" (adhesive and stand-up); "No smoking please-except where indicated" (adhesive); "Smoke-free areas-thank you for not smoking" (adhesive and stand-up). Consultation by government health officials with businesses about the content of the signs resulted in the name of the Act appearing on the signs, so that customers would know that smoking was being prohibited because of the law, not because of management policy. The signs were available free of charge on request at several locations. Signs other than those provided by the government were permitted as long as they met the Act's signage requirements.

The legislation reflects a number of compromises. The original proposal-that restaurants be included among the initial group of premises to be required to go smoke-free-was rejected, and instead a one-year, phasing-in period was adopted, during which time restaurants were required to make at least $50 \%$ of their dining area non-smoking. The Act also specifies 30 months as the phasing-in period for the smoking prohibition in public houses, bars, and social clubs that have licences to serve alcohol. Although the original legislation did not permit exemptions, opposition amendments provided for exemptions to be granted for restaurants (allowing them a maximum $25 \%$ smoking) and licensed premises (maximum 50\% smoking) if they operated sufficiently sophisticated air conditioning and ventilation equipment.

Table 1 Actual and perceived levels of compliance with non-smoking legislation (\%)

\begin{tabular}{lllll}
\hline & & \multicolumn{3}{c}{ Perceived compliance } \\
\cline { 3 - 5 } Actual compliance & $\begin{array}{l}\text { All } \\
(n=938)\end{array}$ & $\begin{array}{l}\text { Complying } \\
(n=731)\end{array}$ & $\begin{array}{l}\text { Planning } \\
\text { compliance } \\
(n=56)\end{array}$ & $\begin{array}{l}\text { Non- } \\
\text { compliant } \\
(n=87)\end{array}$ \\
\hline Full & 22 & 25 & 11 & 9 \\
Partial & 56 & 58 & 46 & 50 \\
None & 22 & 17 & 43 & 41 \\
\hline
\end{tabular}

$\chi^{2}=46.6, \mathrm{df}=4, \mathrm{P}<0.001$.

\section{Methods}

SUBJECTS

A survey was conducted among local businesses to assess the level of awareness and compliance with the legislation. The survey was conducted in two phases. In the first phase, interviewers observed businesses in terms of their type, the presence of no-smoking signage, and the extent to which the businesses appeared to comply with the legislation. In the second phase, the interviewers contacted the manager or an employee of the business, who was asked to complete a short questionnaire. The respondent either handed the completed questionnaire to the interviewer or returned it by mail in a reply-paid envelope. A total of 1488 businesses were observed by the interviewers, with $938(63.0 \%)$ returning a usable questionnaire. These 938 subjects, where we have matched data provided by interviewers and respondents, ${ }^{24}{ }^{25}$ form the basis for the analyses presented here. An analysis of the interviewer-observed businesses that failed to return a questionnaire indicated that they differed little in terms of their location within the private sector compared with those businesses for which we had complete information.

\section{PROCEDURES}

Both phases of the survey were conducted in June 1995, six months after the legislation came into effect. The survey targeted a representative sample of all businesses with enclosed public places within the ACT. The sample size of 1488 represents $7.3 \%$ of all business names registered in the ACT.

\section{SURVEY INSTRUMENT}

The interviewers were required to complete a questionnaire based on their observations of the business premises, including details of signage and evidence of smoking in prohibited areas (reflected in cigarette butts or the smell of tobacco smoke, for example). The interviewers were then instructed to contact the manager or another senior staff member, who was asked to complete a questionnaire. The questionnaire asked about the business's smoking policy before the introduction of the legislation in December 1994 and their current smoking policy, as well as their beliefs about whether the new law affected smoking in their premises and the extent to which their premises met the requirements of the legislation.

\section{Results}

Among the 938 survey respondents for whom complete information was available, $22 \%$ of businesses complied fully with the legislation, based on a visual evaluation of the premises by the interviewers (table 1). This meant that these premises displayed appropriate signage; the interviewers also reported there was also no evidence of smoking in non-smoking areas. Just over half of the premises- $56 \%$ - partially met the legislative requirements by displaying signage either externally or internally in the premises, but not both, as is required by law. The remaining $22 \%$ of the premises failed to 
Table 2 Compliance as a function of business type (\%)

\begin{tabular}{|c|c|c|c|c|c|c|c|}
\hline & \multicolumn{5}{|c|}{ Private sector } & \multirow{2}{*}{$\begin{array}{l}\text { Government } \\
(n=44)\end{array}$} & \multirow{2}{*}{ 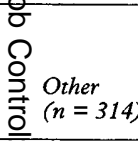 } \\
\hline & $\begin{array}{l}\text { Financial } \\
(n=41)\end{array}$ & $\begin{array}{l}\text { Shop } \\
(n=187)\end{array}$ & $\begin{array}{l}\text { Food } \\
(n=119)\end{array}$ & $\begin{array}{l}\text { Real estate } \\
(n=119)\end{array}$ & $\begin{array}{l}\text { Car } \\
(n=33)\end{array}$ & & \\
\hline Full compliance & 15 & 11 & 22 & 17 & 27 & 11 & $\vec{\Rightarrow} 27$ \\
\hline Technical non-compliance ${ }^{\star}$ & 68 & 52 & 44 & 51 & 24 & 66 & $\stackrel{\oplus}{\rightarrow} 44$ \\
\hline Non-compliance ${ }^{\star}$ & 10 & 15 & 16 & 12 & 6 & 16 & ㅇ 17 \\
\hline Other & 7 & 22 & 18 & 20 & 42 & 7 & 당 12 \\
\hline
\end{tabular}

meet any of the requirements by not displaying the appropriate signage; in a small number of cases-5\%-the interviewers observed evidence of smoking in non-smoking areas.

By contrast, most proprietors or staff who were interviewed- 731 or $84 \%$ of the total number of interviews - believed that they were complying fully with the legislation. A further $6 \%$ of the total said that they were planning to comply at some future date, while $10 \%$ were either unaware of the legislation or knew that they did not comply and had no plans to do so. Among those who believed that they were meeting the requirements (column 2 in table 1), only $25 \%$ were actually compliant, although a further $58 \%$ partially met the requirements. This was generally because they met one or the other of the signage requirements.

The results indicate a considerable discrepancy between how far the businesses met the legislative requirements, and how far the proprietors considered that they met them. Of the total number of premises included in the survey, $21 \%$ complied and correctly assessed their compliance: these businesses were therefore in full compliance. However, by far the largest group, $48 \%$, were businesses which only partially complied but thought that they were in full compliance; these are businesses which were in technical noncompliance with the legislation. A further $15 \%$ were non-compliant but also thought that they were in full compliance: these are what we term non-compliant. The remaining $16 \%$ of businesses were divided between the six remaining categories.

Among the factors that were considered relevant in examining awareness and compliance levels were the type and location of premises and the smoking policy of the establishments, before the legislation coming into effect and when the survey was conducted at the six-month stage. The results in table 2 for the type of business show that a correct assessment was highest among car and other retailers, followed by food retailers, a category which included food stores as well as cafés, restaurants, and takeaways. Complipance was lowest among shop retailers (1.\%) and, surprisingly, among government $\vec{F}$ establishments (also $11 \%$ ). Overall, business कype had a major impact on the level of complance $\left(\chi^{2}=\right.$ $62.1, \mathrm{df}=18, \mathrm{P}<0.001$ ).

$\stackrel{\circ}{+}$

Table 3 shows that the smoking pabjicy of the establishment at the time the legislation came into force was also a major inf(ience on compliance $\left(\chi^{2}=102.6, \mathrm{df}=5, \mathrm{P}<0.001\right)$. No less than $53 \%$ of the businesses thegught that they were compliant but which werêtonly partially compliant had a complete prol 3̈bition on smoking when the survey was condu@ed. Most businesses in this category had a pre-existing policy banning smoking and therefore believed that the legislation did not apply tionthem; in fact, they had to have adequate signage to meet the requirements of the legislation. $T$ This was illustrated by the fact that many of the businesses, when offered the correct IIgnage by the interviewers, refused to take them. Most argued that they were prohibited from placing signs in their windows, either by company policy or by the shopping mall witin which their business was located.

Whether premises were free-stånding or located within shopping malls was alơ statistically significant, with $63 \%$ of busineşes within shopping malls believing that they fore fully compliant when in fact they were only technically compliant. The reasons oappeared to be the retailers' belief that the shoping centre's smoking prohibition also a glplied to individual businesses within the centre, or a belief that a no-smoking policy by the ercompany was sufficient to meet the requirements. Such retailers were surprised to learn that the no-smoking signs at the shopping mall entrances applied only to the common areas of the mall and that they were required signs within their own premises as wed Table 3 reveals a more minor effect on compliance for the seniority of the staff member a who was interviewed, with managers and sefior staff tending to give more accurate information than other staff; their position, presumagly, made

Table 3 Compliance as a function of location, prior smoking policy, and staff member interviewed (\%)

\begin{tabular}{|c|c|c|c|c|c|c|c|c|c|}
\hline & \multicolumn{3}{|c|}{ Premises } & \multicolumn{3}{|c|}{ Smoking policy in 1994} & \multicolumn{3}{|c|}{ Staff memberס } \\
\hline & $\begin{array}{l}\text { Shopping mall } \\
(n=116)\end{array}$ & $\begin{array}{c}\text { Multistory } \\
(n=121)\end{array}$ & $\begin{array}{l}\text { Independent } \\
(n=643)\end{array}$ & $\begin{array}{l}\text { Prohibited } \\
(n=506)\end{array}$ & $\begin{array}{l}\text { Restricted } \\
(n=229)\end{array}$ & $\begin{array}{l}\text { Permitted } \\
(n=132)\end{array}$ & $\begin{array}{l}\text { Manager } \\
(n=365)\end{array}$ & $\begin{array}{l}\text { Senior } \\
(n=179)\end{array}$ & $\begin{array}{l}\text { ÔOther } \\
\text { 으 }(n=298)\end{array}$ \\
\hline $\begin{array}{l}\text { Full compliance } \\
\text { Technical non-compliance } \\
\text { Non-compliance } \\
\text { Other }\end{array}$ & $\begin{array}{l}8 \\
63 \\
20 \\
9 \\
\chi^{2}=38.9, \quad \mathrm{df}=6\end{array}$ & $\begin{array}{l}16 \\
55 \\
18 \\
11 \\
P<0.001\end{array}$ & $\begin{array}{l}24 \\
44 \\
13 \\
20\end{array}$ & $\begin{array}{l}25 \\
53 \\
14 \\
7 \\
\chi^{2}=102.6,\end{array}$ & $\begin{aligned} & 18 \\
& 43 \\
& 15 \\
& 25 \\
&=6, P<0.001\end{aligned}$ & $\begin{array}{l}11 \\
33 \\
14 \\
41\end{array}$ & $\begin{array}{l}22 \\
42 \\
14 \\
22 \\
\chi^{2}=23.2\end{array}$ & $\begin{array}{l}27 \\
47 \\
13 \\
13 \\
=6, P<0.001\end{array}$ & 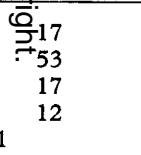 \\
\hline
\end{tabular}


Table 4 Sources of information about the legislation (\%)

\begin{tabular}{llllc}
\hline & $\begin{array}{l}\text { Mass media } \\
(n=282)\end{array}$ & $\begin{array}{l}\text { Business } \\
(n=83)\end{array}$ & $\begin{array}{l}\text { Government } \\
(n=51)\end{array}$ & $\begin{array}{l}\text { Personal } \\
(n=69)\end{array}$ \\
\hline Full compliance $^{\star}$ & 18 & 15 & 10 & 6 \\
Technical non-compliance* $^{*}$ & 47 & 59 & 53 & 49 \\
Non-compliance & 17 & 13 & 23 & 23 \\
Other & 18 & 13 & 14 & 22 \\
\hline
\end{tabular}

$\chi^{2}=498.5, \mathrm{df}=9, \mathrm{P}<0.001$

$\star$ See text for definitions. discrepancy is accounted for by businesses which had a non-smoking policy before the introduction of the legislation. These businesses apparently thought that they complied with the legislation by virtue of their pre-existing policy: they did not realise that appropriate signage was required.

Although inadequate signage may seem a small transgression-the businesses already had a non-smoking policy, thus effectively meeting the legislative requirements - the display of signage was considered of crucial importance in achieving a high level of business and community awareness, as the law was intended to be "self-enforcing". However, despite the lack of signs in the majority of cases, there was no evidence of smoking occurring in most smoking-prohibited premises. This appeared to be partly a consequence of the previously existing non-smoking policy in these businesses, and partly because the display of no-smoking signs at entrances to common areas was misunderstood as applying to individual premises. No-smoking signs may convey the rule without conveying the fact that there is a law (Rigotti et al, unpublished paper and personal correspondence, 1995). If so, achieving compliance with non-smoking legislation may depend less on public knowledge of the law than on strong public support for those rules.

The results presented here suggest that-with the exception of signagebusinesses find few problems in introducing and maintaining a smoke-free workplace. Other studies have found varying levels of compliance. A study in Cambridge, Massachusetts (United States) found that two years after smoke-free legislation had been introduced, $38 \%$ of stores illegally permitted customers or employees to smoke. ${ }^{9}$ By contrast, a recent study of compliance with smoking bylaws in Toronto, Ontario (Canada) found that $90 \%$ of restaurants complied with the law by having at least $50 \%$ of their workplace smoke-free. ${ }^{26}$ Our results are closer to those of the Toronto study, and show that effective non-smoking in a wide range of enclosed public places is possible with minimal opposition. Moreover, like the Canadian study, we found that proprietors were much more likely to mention the advantages rather than the disadvantages of a non-smoking policy.

What implications do these results have for jurisdictions contemplating similar legislation? Perhaps the most important implication is the need for publicity. A no-smoking law should be effectively publicised, simply and factually, to businesses and their customers and clients. Although proprietors have a responsibility to be aware of legislation that affects their business, many said that there was a lack of government information about this law. The absence of an effective information programme will result in businesses being uninformed or misinformed about the law and believing that they are complying when they are not, leaving them (and their customers) liable to legal action. Personal visits were found to be to apply smoking restrictions uniformly across all public places and one of the first in the world. Our major conclusion is that there is a substantial discrepancy between perceived compliance and actual compliance. Part of this 
effective, notably in the case of small, independent businesses in isolated areas.

Two other points also emerged from the evaluation of compliance with the ACT legislation. First, health authorities should take advantage of community norms and support by first implementing legislation in premises where public support will contribute to high levels of compliance, such as shops and shopping centres. Once the principle of prohibition is accepted in these areas, it is easier to extend the ban to other public areas, such as hotels and clubs. Second, pre-existing no-smoking policies contribute to businesses being more relaxed about the effect of the legislation, because they are not faced with making a major change, but it also often confuses them about their actual legal obligations. It may therefore be necessary to target information to those businesses with pre-existing no-smoking policies.

The survey data used in this paper were collected by the Australian Capital Territory Department of Health and Community Care. The department is not responsible for the views and opinions expressed herein. Our thanks to Dr Michael Cummings and two anonymous reviewers for their constructive comments on an earlier draft of the paper.

1 US Department of Health and Human Services. The health consequences of involuntary smoking. A report of the Surgeon General, 1986. Rockville, Maryland: Public Health Service, Centers for Disease Control, 1986. (DHHS Publication No (CDC) 87-8398.)

2 US Environmental Protection Agency. Respiratory health effects of passive smoking: lung cancer and other disorders. Washington, DC: Office of Research and Development 1992. (Publication No EPA/600/6-90/006F.)

3 National Health and Medical Research Council. Effects of passive smoking on health. Canberra: Australian Government Publishing Service, 1987.

4 National Health and Medical Research Council. The health effects of passive smoking: draft report of the working party. Canberra: Australian Government Publishing Service,

5 Schofield MJ, Considine R, Boyle CA, et al. Smoking control in restaurants: the effectiveness of self-regulation in Australia. Aust $\mathcal{F}$ Public Health 1993;83:1284-8.

6 Dalla-Vorgia V, Sasco AJ, Skaikidis Y, Katsouyanniu K, Trichopoulos D. An evaluation of the effectiveness of tobacco-control legislative policies in the European Community countries. Scand $\mathcal{f}$ Soc Med 1990;18:81-9.
7 European Bureau of Action on Smoking Prevention. Tobacco and health in the European Union: an overegew. Brussels: European Bureau of Action on Smoking Prevention, 1994.

8 Naett C, Howie C. Passive smoking: results $\propto$ a European survey. Tobacco Control 1993;2:165.

9 Rigotti N, Stoto M, Bierer M, et al. Retail stor with a city no-smoking law. Am $¥$ \$ublic Health with a city

10 Stanwick RS, Thomson MP, Swerhone P $\overrightarrow{\text {, }}$, et al. The response of Winnipeg retail shops and restaurants to a bylaw regulating smoking in public placesoCan $\mathcal{F}$ Public Health 1988;79:226-30.

11 Glantz S, Smith LRA. The Effect of ordina $\frac{\overline{5}}{3}$ es requiring smoke-free restaurants on restaurant sales $\mathrm{Am} \mathcal{F}$ Public Health 1994;84:1081-5.

12 Maroney N, Sherwood D, Stubblebine $\mathrm{WC}_{\mathrm{\Omega}}^{\mathrm{T}}$ The impact of tobacco control ordinances on restaurant revenues in California. Clarement, California: Clarement Institute for Economic Policy Studies, 1994.

13 Taylor Consulting Group. The San Luis Obisp $\overrightarrow{\underline{0}}$ smoking ordinance: a study of the economic impacts on San Lais Obispo restaurants and bars. San Luis Obispo, Cal obrnia: Taylor taurants and bars. San L
Consulting Group, 1993.

तु

4 US Centers for Disease Control and Preverution. Assess-
ment of the impact of a $100 \%$ smoke-freeprdinance on ment of the impact of a $100 \%$ smoke-freeprdinance on
restaurant sales-West Lake Hills, Texais 1992-1994. MMWR 1995;44:370-2.

15 Borland R, Hill DJ. Public attitudes to smoke-free zones in restaurants. Med $\mathcal{F}$ Aust 1989;150:407.

16 Borland R, Hill DJ. Public attitudes to smoke-free zones in restaurants-an update. Med $\mathcal{F}$ Aust 1991;1 \&4292-93.

17 Makkai T, McAllister I, Goodin M, Public kn @wledge about passive smoking: results from a survey in Re Australian Capital Territory. Int $\mathcal{F}$ Addict 1994;29:415- 37 .

18 McAllister I. Public opinion in Australia on restricting smoking in public places. Tobacco Control 10 5; $4: 30-5$.

19 Rigotti N, Stoto M, Schelling T, Do businessegtcomply with a no-smoking law? Assessing the self-enfofcement approach. Prev Med 1994;23:223-9. v

20 Kagan RA, Skolnick JH. Banning smoking compliance without enforcement. In: Rabin R, Sugarman SD, eds. Smoking policy: law, politics and culture. New York: Oxford University Press, 1993.

21 Rabin, R, Sugarman SD, eds. Smoking policy: $\overline{\bar{L}} w$, politics and culture. New York: Oxford University Press, \$993.

22 National Heart Foundation (ACT Division). Batacol survey of community attitudes towards smoking in public places, November/December 1991. Canberra: Nation娄Heart Foundation, 1992.

23 Goodin $M$. Clean indoor air legislation in Austal Goodin M. Clean indoor air legislation in Australia. Tobacco
Control 1995;4:294.

24 Cheadle A, Psaty BM, Curry S, et al. Can measures of the grocery store environment be used to tracecommunitylevel dietary-changes? Prev Med 1993;22:36 P 72 .

25 Cheadle A, Wagner E, Koepsell T, Kristal A. Kavironmental indicators: a tool for evaluating community promotion programs, Am $\mathcal{F}$ Prev Med 1992;8345-50.

26 Ying JYC, Abernathy T, Choi BCK, A comprehensive evaluation of the 1993 City of Toronto smelking bylaws. Rev Can Sante Publique 1995;86:32-6. 